Jurnal Sporta Saintika

P-ISSN 2502-5651

E-ISSN 2579-5910

\title{
PENGARUH UMPAN BALIK, KOORDINASI TERHADAP KEMAMPUAN OBJEK KONTROL SISWA PAUD
}

\author{
Syahrial Bakhtiar ${ }^{1}$, Khairuddin $^{2}$, Reki Yelis ${ }^{3}$, Oktarifaldi $^{4}$, Lucy Pratama Putri ${ }^{5}$, Suci Nanda Sari ${ }^{6}$ \\ ${ }^{123456}$ Universitas Negeri Padang, Pendidikan Jasmani Kesehatan dan Rekreasi, Padang, \\ Indonesia
}

syahrial@fik.unp.ac.id ${ }^{1}$, khairuddin@fik.unp.ac.id $^{2}$, rekiyelis13@gmail.com $^{3}$, ,oktarifaldi88@fik.unp.ac.id $^{4}{ }_{2}$ lucy.pratama@fik.unp.ac.id ${ }^{5}$ sucinandasari1606@gmail.com ${ }^{6}$

\begin{abstract}
The problem in this study is the low ability of the object of control of kindergarten students in Padang Panjang City of Trustees. The ability of the control object is influenced by many factors, including the learning strategy used on the ability of object control students in TK Padang Panjang. This research uses quasy experiment design. The population in this study were all kindergarten students in Padang Panjang, amounting to 80 people. The sampling technique is done by total sampling. Control object capability data is obtained by giving the TGMD-2 test. Data were analyzed using a two-way variant analysis (ANAVA) technique with a 2x2 factorial design. The results of research and data analysis show that: 1) There is a difference in the ability of basic movement skills between groups of children who are given a direct feedback of indirect feedback with a value of $Q$ 4.19> Qtable 2.95). 2) There is a difference high coordination and a child who has a low coordination Q count 5.91> Qtable 2.95. 3) There is an interaction between feedback with the level of coordination towards the mastery of basic child movement skills which is shown with a value of $0.000<0.05$. 4) There is a difference in the ability of basic child movement skills between groups who have a high coordination with direct feedback with the calculation of the value of $Q$ count $12.03>Q$ table 3.15. 5) There is a difference in the ability of basic movement skills of children between groups of children who have a low coordination given indirect feedback with children who are given direct feedback with a $Q$ count value of 4.03> Qtable 3.15
\end{abstract}

Keywords: coordination, feedback, object control.

\begin{abstract}
Abstrak
Masalah dalam penelitian ini adalahkemampuan objek kontrol siswa PAUD Kota Padang Panjang yang rendah. Kemampuan objek kontrol dipengaruhi oleh banyak faktor, termasuk sfeedback saat pembelajaran. Penelitian ini bertujuan untuk melihat pengaruh feedback langusng dan tidak langsung terhadap kemampuan objek kontrol siswa PAUD Padang Panjang. Jenis penelitian ini adalah experimen semu. Populasi dalam penelitian adalah sebanyak 80 orang dan sampel diambil menggunakan teknik total sampling. Instrumen yang digunakan untuk kemampuan objek kontrol adalah TGMD-2. Data dianalisis dengan ANAVA faktorial 2x2. Hasil penelitian memperlihatkan bahwa: (1) Kemampuan objek kontrol anak yang diberi feedback langsung lebih baik dengan $Q_{\text {hitung }} 5.91>Q_{\text {table }} 2.95$, (2) Kemampuan objek kontrol anak yang memiliki koordinasi tinggi lebih baik dari yang rendah dengan $Q_{\text {hitung } 4.19>}$ Qtable 2.95, (3) Terdapat interaks antara feedback dengan koordinasi terhadap kemampuan objek kontrol dengan Sig $0.000<0.05$, (4) Kemampuan objek kontrol anak koordinasi tinggi pada feedback langsung lebih baik dari feedback tidak langsung $Q_{\text {hitung }}$ 12.03> Qtable 3.15, (5) Kemampuan objek kontrol anak koordinasi rendah dengan feedback tidak langsung lebih baik dari feedback langsung $Q_{\text {hitung }} 4.03>Q_{\text {table }}$ 3.15.
\end{abstract}

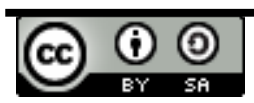

Volume 5, Nomor 1, Maret 2020 sportasaintika.ppj.unp.ac.id 
Jurnal Sporta Saintika

P-ISSN 2502-5651

E-ISSN 2579-5910

Kata kunci: feedback, koordinasi, objek kontrol.

\section{PENDAHULUAN}

Keterampilan gerak dasar dianggap sebagai dasar untuk kompetensi gerak (Ting Liu Getchel 2011). Juga disebutkan bahwa keterampilan gerak dasar dianggap sebagai dasar untuk membangun gerakan yang lebih kompleks dimasa datang (Clark \& Metcalfe 2002; Robinson \& Goodway 2009). Selain itu dengan memiliki keterampilan gerak dasar yang baik akan memberikan dampak kesehatan bagi anak-anak (Piek et al. 2008). Keterampilan gerak dasar ini harus diajarkan pada anak usia dini, sekitar 3 sampai 5 tahun karena pada usia ini merupakan masa emas bagi pertumbuhan dan perkembangan fisik, motorik, kognitif serta social anak (Shenouda, 2011) (Stodden et al., 2008). Keterampilan gerak dasar ini bisa dimiliki oleh anak secara alami melalui proses pendewasaan dan kematangan (Malina, Bouchard, \& Bar-Or, 2004). Namun hal yang harus diingat adalah perkembangan dari keterampilan gerak dasar ini tidak berbanding lurus dengan usia, malah sebaliknya. Oleh sebab itu perlu diberikan latihan secara rutin agar dapat meningkatkan keterampilan gerak dasar ini (Shenouda, 2011)( Clark JE, Metcalfe, 2002).

Keterampilan gerak dasar ini diajarkan melalui berbagai pendekatan, diantaranya adalah dengan (1) hanya memberikan instruksi keterampilan gerak dasar, (2) mellaui permainan dan olahraga (3) melalui aktivitas fisik, (4) melalui video game, (5) pengembangan guru professional dan (6) pendekatan multikomponen (Tompsett et al,2017). Juga harus diperhatikan bahwa didalam pembelajaran gerak diharapkan terjadinya interaksi. Salah satunya umpan balik selama proses pembelajran. Mengoptimalkan pembelajaran feedback sangat dibutuhkan, Feedback mengajarkan anak-anak untuk menilai penampilan, yang mana mereka tidak dapat melihat dan merasakan kesalahan sendiri, karena peserta didik lain yang dapat melihat dan mengevaluasi hal tersebut. Kemudian daripada itu, guru diharapkan mampu menggunakan feedback dalam berbagai bentuk. Namun kenyataan nya feedback jarang menjadi perhatian didalam pembelajaran dan sering dilupakan guru-guru dan pelatih dalam melangsungkan kegiatan tersebut.

Stodden (2008) menerangkan bahwa unsur-unsur yang terkandung dalam kemampuan motorik yaitu: a) Kekuatan, b) Koordinasi, c) Kecepatan, d) Keseimbangan dan e) Kelincahan. Objek kontrol lebih menekankan pada keterampilan motorik kasar yang menunjukkan gerakan melempar, memukul, dan menangkap yang efisien (Ulrich, 2000). Berdasarkan penelitian Kelincahan, Koordinasi dan Keseimbangan berpengaruh secara 
Jurnal Sporta Saintika

P-ISSN 2502-5651

E-ISSN 2579-5910

langsung terhadap keterampilan gerak dasar termasuk kemampuan lokomotor siswa (Oktarifaldi, 2019). Dengan demikian dalam realisasi gerak dasar bagi anak perlu mengembangkan unsur-unsur mendukung seperti koordinasi gerakan, terutama dalam realisasi gerak lokomotor hingga gerak objek kontrol yang dominan dengan manipulasi alat.

Koordinasi merupakan unsur fisik dalam mengintegrasikan semua gerakan yang kompleks termasuk objek kontrol. Koordinasi adalah faktor penting yang nantinya akan berpengaruh terhadap keterampilan gerak dasar yang dimiliki oleh anak serta pada jenjang pendidikan yang lebih tinggi (Lupu, 2011; Tsapakidou, A., Stefanidou, S., \& Tsompanaki, E, 2014). Kiram (1994) menerangkan "koordinasi merupakan hubungan timbal balik antara pusat susunan syaraf dengan alat gerak dalam mengatur dan mengendalikan impuls dan kerja otot untuk pelaksanaan suatu gerakan". Dapat dipahami koordinasi merupakan hubungan kerjasama antara susunan saraf pusat dengan alat gerak saat berkontraksi dalam menyelesaikan tugas-tugas motorik atau perpaduan gerak yang saling berkaitan. Gerak tersebut akan menghasilkan keterampilan gerak secara tepat dan terarah termasuk dalam merealisasikan gerak lokomotor secara efektif dan efisien.

Observasi yang telah dilakukan memperlihatkan bahwa tidak lebih dari 7\% anak-anak yang memiliki keterampilan gerak dasar yang baik. Padahal keterampilan gerak dasar ini sangat dibutuhkan untuk kecakapan sepanjang hidup, tidak hanya untuk melakukan aktivitas olahraga, namun juga aktivitas fisik, social dan masih banyak lagi. Keterampilan gerak dasar ini seharusnya diajarkan sejak jenjang pendidikan terbawah, yaitu Pendidikan Anak Usia Dini (PAUD). Namun pada kenyataanya, hal ini tidak terjadi karena guru PAUD masih belum paham bagaimana cara mengimplementasikan pembelajaran gerak dasar. Hal juga mencengangkan adalah guru-guru ini sama sekali tidak pernah tahu apa itu gerak dasar, terkhususnya di Sumatera Barat (Syahrial, Famelia, 2017). Hasil penelitian serta observasi yang penulis lakukan menjadi tolak ukur dan permasalahan inti yang perlu dipecahkan. Hasil penelitian secara kontiniu yang penulis lakukan melahirkan ide baru untuk memberikan solusi permasalahan dengan mengadakan eksperimen di kota Padang Panjang dengan sampel siswa TK dan PAUD tepatnya Gugus Kejora di kecamatan Padang Panjang Barat.

\section{METODELOGI PENELITIAN}

Metode yang digunakan dalam penelitian ini adalah eksperimen semu (quasy experimen design), sesuai yang dikemukakan Iskandar (2008:64): "penelitian eksperimen merupakan penelitian yang menuntut peneliti memanipulasi dan mengendalikan satu atau lebih variabel bebas serta mengamati variabel terikat, untuk melihat perbedaan 
Jurnal Sporta Saintika

P-ISSN 2502-5651

E-ISSN 2579-5910

sesuai dengan manipulasi variabel bebas (independent) tersebut atau penelitian yang melihat hubungan sebab akibat kepada dua atau lebih variabel dengan memberikan lebih (treatment) kepada kelompok eksperimen.

Teknik sampling yang digunakan dalam penelitian ini adalah purposive sampling, yaitu sampel yang diambil dengan pertimbangan tertentu oleh peneliti (Sugiyono, 2016). Didasarkan atas pertimbangan tersebut, maka sampel dalam penelitian ini hanya berjumlah 80 orang. Tes koordinasi menggunakan subtest $M-A B C$, yaitu aiming and catching. Data kemampuan objek kontrol dikumpulkan dengan menggunakan instrumen Test of Gross Motor Skill Second Edition (TGMD-2) (Ulrich, 2000) terdiri dari 6 skill yang harus dikuasai dengan baik oleh sampel, skill tersebut adaah: strike, catch, dribble, kick, throw and roll. Tes ini dilakukan sebanyak 3 kali untuk setiap sampel, tes yang akan dinilai adalah yang kedua dan yang ketiga. Sementara tes pertama hanya sebagai percobaan. Masing-masing skill yang terdapat dalam TGMD-2 terdiri dari beberapa kriteria yang harus terpenuhi. Jika kriteria terpenuhi maka akan diberikan nilai 1 , sebaliknya jika tidak terpenuhi akan diberikan nilai 0 . Setiap skor yang diperoleh dari masing-masing kriteria akan dijumlah untuk mendapatkan skor akhir.

Penelitian iniakan menggunakan disain Faktorial 2x2 by level, dimana masing-masing variabel bebas diklasifikasikan menjadi 2 bentuk pendekatan belajar $(A)$, yaitu feedback langsung(A1) dan feedback tidak langsung (A2), sedangkan variabel atribut/moderator diklasifikasikan dalam 2 bentuk tingkatan kemampuan koordinasi (B), yaitu koordinasi tinggi (B1) dan koordinasi rendah (B2).

\section{HASIL PENELITIAN}

Tabel 1. Distribusi Frekuensi Data Kemampuan Objek Kontrol Siswa Pendidikan Anak Usia Dini Kota Padang Panjang

Objek Kontrol

\begin{tabular}{|c|c|c|c|c|c|c|c|}
\hline \multirow[b]{2}{*}{$\mathbf{N}$} & \multicolumn{3}{|c|}{ Male } & & \multicolumn{3}{|c|}{ Female } \\
\hline & $\begin{array}{c}\text { Percentile } \\
\text { Rank }\end{array}$ & $\begin{array}{l}\text { Frekuensi } \\
\text { Relatif }\end{array}$ & $\%$ & $\mathbf{N}$ & $\begin{array}{c}\text { Percentile } \\
\text { Rank }\end{array}$ & $\begin{array}{c}\text { Frekuensi } \\
\text { Relatif }\end{array}$ & $\%$ \\
\hline \multirow{4}{*}{38} & $<1$ & 31 & $82 \%$ & \multirow{4}{*}{42} & $<1$ & 35 & $83 \%$ \\
\hline & 1 & 3 & $8 \%$ & & 1 & 0 & $0 \%$ \\
\hline & 2 & 1 & $3 \%$ & & 2 & 2 & $5 \%$ \\
\hline & 3 & 3 & $8 \%$ & & 3 & 1 & $2 \%$ \\
\hline
\end{tabular}


Jurnal Sporta Saintika

P-ISSN 2502-5651

E-ISSN 2579-5910

Berdasarkan tabel distribusi frekuensi data penelitian di atas, dapat diketahui bahwa dari 80 orang siswa Pendidikan anak usia dini di kota padang panjang yang terdiri dari 38 orang siswa laki-laki dan 42 orang siswa perempuan. Dari total 38 orang siswa laki-laki terdapat sebanyak 31 orang atau $82 \%$ yang memiliki kemampuan objek kontrol pada percentile rank $<1$. Kemudian sebanyak 3 orang atau $8 \%$ pada yang memiliki kemampuan objek kontrol pada percentile rank 1. Pada percentile rank 2 terdapat sebanyak 1 orang atau $3 \%$. Selanjutnya terdapat sebanyak 3 orang atau $8 \%$ anak yang memiiki kemampuan objek kontrol pada percentile rank 3.

Siswa perempuan yang diukur kemampuan objek kontrolnya, ditemukan sebanyak 35 orang atau $83 \%$ yang memiliki kemampuan objek kontrol pada percentile rank $<1$. Pada percentile rank 1 tidak terdapat satu orang pun anak, kemudian pada percentile rank 2 terdapat sebanyak 2 orang anak atau 5\%. Terakhir, ditemukan sebanyak 1 orang anak atau $2 \%$ yang memiliki kemampuan objek kontrol pada percentile rank 3 .

\section{Uji Normalitas}

Untuk mengetahui apakah sebaran data berdistribusi normal atau tidakdilakukukan dengan membandingkan nilai koefisien Sig dengan nilaiprobabilitas $\alpha=0.05$. dengan kriteria pengambilan keputusan jikanilai sig $>0.05$ maka data berasal dari distribusi yang normal. Sebaliknya apabila nilai koefisien Sig<0.05 maka data berasal dari distribusi yang tidak normal. Berikut penulis telah buat rangkuman hasil uji normalitas data penelitian.

Tabel 2. Rangkuman Uji Hipotesis Data Penelitian

\begin{tabular}{|l|l|l|c|c|}
\hline No & \multicolumn{1}{|c|}{ Subjek } & $\begin{array}{c}\text { Sig. } \\
\text { Kolmogorov- } \\
\text { Smirnov }\end{array}$ & $\begin{array}{c}\alpha=05 \\
\mathbf{0 . 0 5}\end{array}$ & Keterangan \\
\hline 1 & Feedback langsung & 0.200 & \multirow{2}{*}{0.05} & Normal \\
\hline 2 & Feedback tidak langsung & 0.200 & \\
\hline 3 & Koordinasi tinggi & 0.200 & \\
\hline 4 & Koordinasi rendah & 0.200 & \\
\hline 5 & $\begin{array}{l}\text { Feedback } \\
\text { koordinasi tingi langsung }\end{array}$ & 0.200 & \\
\hline 6 & $\begin{array}{l}\text { Feedback langsung } \\
\text { koordinasi rendah }\end{array}$ & 0.200 & \\
\hline 7 & $\begin{array}{l}\text { Feedback tidak langsung } \\
\text { koordinasi tingi }\end{array}$ & 0.200 & \\
\hline
\end{tabular}


Jurnal Sporta Saintika

P-ISSN 2502-5651

E-ISSN 2579-5910

\begin{tabular}{|l|l|l|l|}
\hline & Feedback tidak langsung & 0.200
\end{tabular}

8 koordinasi rendah

Berdasarkan table 2 di atas, semua subjek yang diukur normalitasnya memiliki nilai Sig Kolmogorov-Smirnova $0.200>\alpha=0.05$. Maka sesuai dengan prasyaratnya, bahwa semua data dalam penelitian ini berdistribusi normal.

\section{Uji Hipotesis}

1. Terdapat perbedaan kemampuan keterampilan gerak dasar object controlantara kelompok anak yang diberi feedback langsung dan tidak langsung

Berdasarkan hasil penghitungan nilai rata-rata kemampuan gerak dasar antara kelompok anak yang diberikan feedback langsung dan tidak langsung, ditemukan bahwa kemampuan gerak dasar anak yang diberikan feedback langsung memiliki nilai rat-rata yang lebih tinggi jika dibadingkan dengan keterampilan gerak dasar anak yang diberikan tidak langsung dengan nilai Qhitung 4,19> Qtabel 2,95.

2. Terdapat perbedaaan keterampilan objek kontrol anak dengan koordinasi tinggi dan rendah

Berdasarkan hasil penghitungan nilai rata-rata kemampuan objek kontrol antara kelompok anak yang memiliki koordinasi tinggi dengan kelompok anak yang memiliki koordinasi rendah, ditemukan bahwa anak kemampuan objek kontrol anak yang memiliki koordinasi tinggi nilai rata-rata yang lebih tinggi jika dibadingkan dengan kemampuan objek kontrol anak yang memiliki koordinasi rendah dengan nilai Qhitung 5,95 > Qtabel 2,95.

3. Terdapat interaksi antara feedback dengan koordinasi terhadap penguasaan kemampuan objek control

Apabila nilai Sig dari feedback*koordinasi lebih kecil dari 0,05 maka dapat disimpulkan bahwa feedback*koordinasi memang berpengaruh terhadap kemampuan obejk kontrol siswa PAUD Padang Panjang. Berdasarkan tabel output Tests of Between-Subjects Effects di atas didapatkan nilai Sig 0,000< 0,05. Maka dapat disimpulkan bahwa strategi* body mass index berpengaruh signifikan terhadap kemampuan gerak dasar anak TK Pembina Padang Panjang. 
Jurnal Sporta Saintika

P-ISSN 2502-5651

E-ISSN 2579-5910

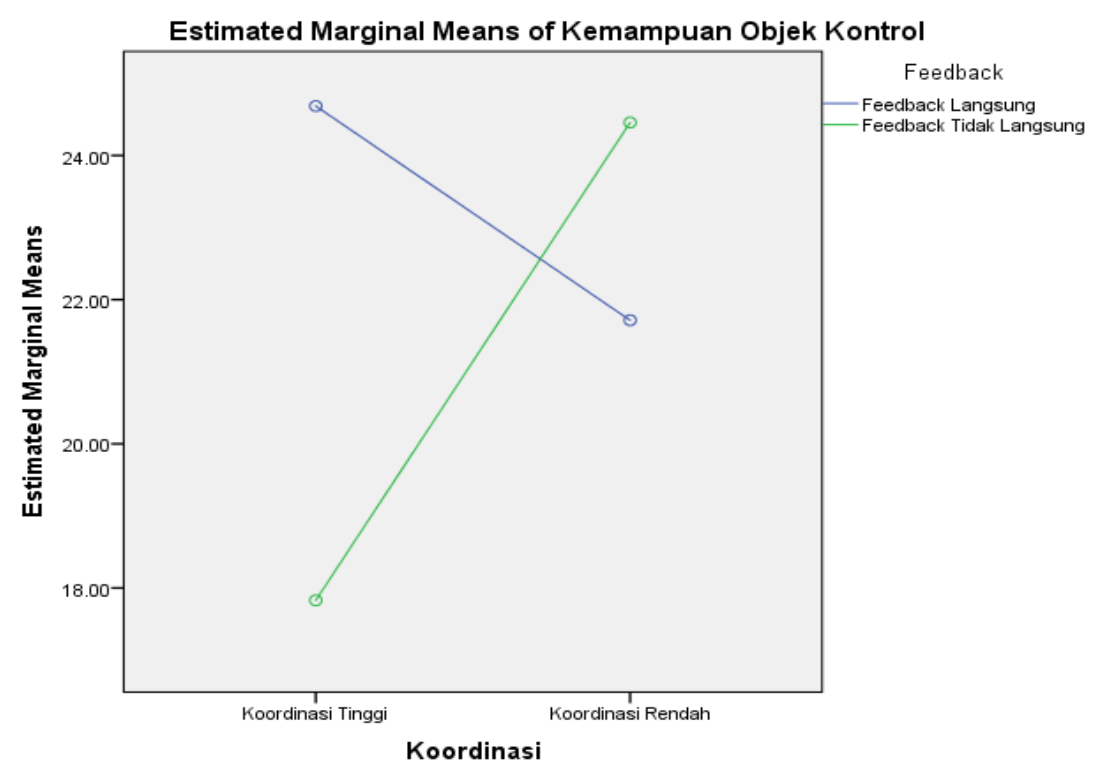

Setelah didapatkan interaksi antar variable, maka dilakukan uji lanjut dengan uji tukey untuk melihat kelompok mana yang memiliki perbedaan secara signifikan.

4. Terdapat perbedaan kemampuan objek kontrol anak antara kelompok anak yang meliki koordinasi tinggi diberi feedback langsung dengan anak yang diberi feedback tidak langsung

Berdasarkan hasil perhitungan ternyata anak yang diberikan feedback langsung koordinasi tinggi lebih baik dibandingkan dengan feedback tidak langsung koordinasi tinggi dengan nilai Qhitung 12,03> Qtabel 3,15. Maka hipotesis yang diajukan dapat diterima, bahwa memang terdapat perbedaan kemampuan objek kontrol siswa yang diberikan feedback langsung koordinasi tinggi dan feedback tidak langsung koordinasi tinggi.

5. Terdapat perbedaan kemampuan objek kontrol anak antara kelompok anak yang memiliki koordinasi rendah diberi feedback langsung dengan anak yang diberi feedback tidak langsung

Berdasarkan hasil perhitungan ternyata anak yang diberikan feedback tidak langsung dengan koordinasi rendah lebih baik dibandingkan dengan yang diberikan feedback langsung dengan koordinasi rendah dengan nilai Qhitung 4,03> Qtabel 3,15. Maka hipotesis yang diajukan dapat diterima, bahwa memang terdapat perbedaan kemampuan objek kontrol siswa yang diberikan feedback tidak langsung dan feedback langsung dengan koordinasi rendah. 
Jurnal Sporta Saintika

P-ISSN 2502-5651

E-ISSN 2579-5910

\section{PEMBAHASAN}

Keterampilan gerak dasar dianggap sebagai dasar untuk kompetensi gerak (Ting Liu Getchel 2011). Keterampilan gerak dasar ini adalah penyempurnaan dari bentuk gerakan dasar seperti berlari dan melempar yang akan digunakan oleh anak sepanjang hidup mereka (Clark dan Metcalfe, 2002). Menurut Gallahue, Ozmun dan Goodway (2012), keterampilan gerak dasar yang sangat penting bagi anak usia dini terbagi atas dua bentuk, yaitu lokomotor dan objek kontrol. Diterangkan bahwa gerak dasar utama merupakan pola gerak yang inherent yang membentuk dasar-dasar untuk gerak-gerak terampil yang kompleks dan khas meliputi : (1) gerak-gerak lokomotor, (2) gerak non lokomotor, (3) gerak manipulative (Gusril, 2015). Kemampuan gerak yang dimiliki oleh anak dalam keterampilan gerak dasar menggambarkan derajat penguasaan keterampilan dalam menggunakan jari-jari tangan, koordinasi mata-tangan dan mata-kaki, tempo-keseimbangan, serta persepsi visual (Bakhtiar, 2014).

Kemampuan menguasai objek (Objec Control) merupakan bagian dari keterampilan gerak dasar atau fundamental motor skill yang harus dipelajari dan diajarkan kepada anak karena keterampilan object control ini nantinya akan berpengaruh dalam kesuksesan mempelajari berbagai keterampilan teknik olahraga, permainan, menari dan keterampilan gerak lainnya (Gallahue, Azmund, Goodway. 2012). Gerak dasar harus dilakukan baik itu pada anak-anak, remaja dan dewasa sebagai proses utama yang akan mempengaruhi kemampuan aktivitas fisik (Stodden, et al, 2008). Keterampilan gerak dasar ini hanya bisa berkembang apabila diberikan instruksi yang jelas serta pengulangan sebagai bentuk latihan karena tidak akan berkembang seiring dengan bertambahnya usia seorang anak (Gallahue, Azmund, Goodway. 2012).(Gallahue daan Ozmund, 2006).

Hasil penelitian yang telah dilakukan oleh Universitas MacMaster Kanada, menemukan bahwa anak yang lebih sering melakukan aktivitas fisik memiliki tingkat kemampuan gerak yang lebih baik, sebaliknya anak yang hanya melakukan aktivitas fisik beberapa kali saja dalam seminggu memiliki tingkat kemampuan gerak dasar yang lebih rendah pula (McMaster University, Kanada., 2011). Berdasarkan hasil penelitian ini, setelah dilakukan treatment dan pengelompokan sampel dilakukan antara anak yang memiliki koordinasi tinggi dan rendah terbukti bahwa terdapat perbedaan kemampuan objek kontrol siswa, baik siswa yang diberikan feedback langsung dan tidak langsung dengan koordinasi tinggi maupun rendah. Selanjutnya terdapat perbedaan kemampuan objek kontrol siswa yang diberikan feedback tidak langsung dan feedback langsung. Artinya yaitu feedback dan 
Jurnal Sporta Saintika

P-ISSN 2502-5651

E-ISSN 2579-5910

koordinasi sangat berpengaruh dalam belajar gerak bagi anak dakam meningkatkan kemampuan gerak dasar khususnya objek kontrol.

Didalam pembelajaran gerak diharapkan terjadinya interaksi, salah satunya umpan balik selama proses pembelajaran. Mengoptimalkan pembelajaran feedback sangat dibutuhkan, Feedback mengajarkan anak-anak untuk menilai penampilan, yang mana mereka tidak dapat melihat dan merasakan kesalahan sendiri, karena peserta didik lain yang dapat melihat dan mengevaluasi hal tersebut. Kemudian daripada itu, guru diharapkan mampu menggunakan feedback dalam berbagai bentuk. Namun kenyataannya feedback jarang menjadi perhatian didalam pembelajaran dan sering dilupakan guru-guru dan pelatih dalam melangsungkan kegiatan tersebut. Dalam pembelajaran gerak faktor pemberian umpan balik (feedback) menurut Nicaise, Cogerind, Bois, Amoroso (2006) dalam berbagai bentuknya akan sangat mempengaruhi keberhasilan belajar, bentuk-bentuk feedback tersebut mulai dari yang bersifat umum, khusus, sederhana, positif, negatif serta netral, baik yang diberikan langsung, pada saat pelaksanaan gerak ataupun yang diberikan langsung, ketika pelaksanaan gerak ataupun yang diberikan secara tunda setelah sesi latihan, baik yang diberikan dalam bentuk pengetahuan tentang hasil (Konwledge of Result) atau dalam bentuk pengetahuan tentang penampilan (Konwledge of Performance).

Lee, Keh dan Magil (1993), Schmidt dan Werisberg (2008) mengemukakan umpan balik (FB) dapat diklasifikasikan dalam banyak cara, salah satunya sangat dikenal adalah antara pengetahuan tentang penampilan (Knowledge of performance/KP) dan pengetahuan tentang hasil (Knowledge of result/KR), KP mengacu kepada karakteristik gerak (komponen pentingnya) juga mengacu kepada proses gerak. Sedangkan KR mengacu kepada hasil. KP berisi tentang anjuran untuk melanjutkan proses pembelajaran, ataupun berupa larangan berisi evaluasi. Sedangkan KR berisi tentang bagaimana peserta didik berkreasi untuk mencapai proses dengan mengutamakan hasil dari pada proses.

Silverman, Tyson dan Krampitz (1992) mengemukakan umpan balik akan mendorong anak untuk melanjutkan latihan/ berlatih karena mereka mengetahui bahwa guru memperhatikan mereka bergerak. Ketika guru memberikan umpan balik mereka juga berkesempatan mengamati lingkungan tempat belajar, dan ini merupakan pembelajaran yang efektif karena pada saat ini, murid merasa sangat diperhatikan, dan ini mereka anggap sebagai motivasi untuk diri mereka dan menimbulkan gairah atau semangat untuk melanjutkan materi pembelajaran yang diberikan oleh guru. Umpan balik mengajarkan anakanak untuk menilai penampilan, yang mana mereka tidak dapat melihat dan merasakan kesalahan diri sendiri, sebab peserta didik lain yang dapat melihat dan mengevaluasi hal 
Jurnal Sporta Saintika

P-ISSN 2502-5651

E-ISSN 2579-5910

tersebut. Umpan balik memungkinkan guru menilai masing-msing individu untuk menentukan seberapa cepat dan benar mereka belajar melalui pengamatannya.

Disamping itu kemampuan koordinasi merupakan salahsatu komponen dari kemampuan kesegaran jasmani yang berkaitan dengan keterampilan seseorang, dapat dikatakan memiliki kemampuan keterampilan tergambar dari seberapa baiknya tingkat koordinasi yang dimiliki. Oktarifaldi (2019) menerangkan koordinasi bermanfaat dalam menyelesaikan tugas-tugas motorik atau perpaduan gerak yang saling berkaitan bagi seseorang termasuk anak-anak. Berdasarkan hasil riset bahwa, dengan meningkatnya kompleksitas gerakan, tingkat koordinasi yang diperlukan untuk melakukan aktivitas juga meningkat, dan keterampilan koordinatif diklasifikasikan sebagai pembelajaran motorik, pemanduan motorik, adaptasi motorik dan keterampilan mengubah arah (Altinkök, 2016). Kemampuan koordinasi, merupakan hal yang menentukan untuk proses mempelajari keterampilan gerak. Menurut Gallahue Ozmund, Goodway (2012) kemampuan tugas gerak yang komplek akan sangat besar dipengaruhi oleh tingkat kemampuan koordinasi. Tingkat koordinasi gerak dasar merupakan faktor penting yang mendorong aktivitas fisik anak sejak usia dini (Ingrid, 2016). Dengan demikian seseorang yang memiliki kemampuan koordinasi yang baik akan mudah untuk mempelajari berbagai keterampilan gerak, guru diharapkan mampu meningkatkan kemampuan koordinasi anak sekaligus mampu mencarikan metode pembelajaran yang paling tepat untuk membantu anak yang mermiliki keterampilan koordinasi yang kurang baik. Untuk itu faktor pembelajaran, pemberian feedback dan koordinasi sangat berpengaruh terhadap pencapaian prestasi belajar objek kontrol. Keterampilan objek kontrol ini mesti diajarkan dengan baik, karena dari hasil penelitian menunjukkan pencapaian pembelajaran objek kontrol ini lebih sulit diraih dibandingkan dengan mempelajari ketrampilan gerak dasar lainnya.

\section{KESIMPULAN}

Berdasarkan hasil penelitian penelitian yang telah dijabarkan di atas, kesimpulan yang didapatkan adalah:

- Terdapat perbedaan kemampuan keterampilan gerak dasar object control antara kelompok anak yang diberi feedback langsung dan tidak langsung, ditemukan bahwa kemampuan gerak dasar anak yang diberikan feedback langsung memiliki nilai rata-rata yang lebih tinggi jika dibadingkan dengan keterampilan gerak dasar anak yang diberikan tidak langsung dengan nilai Qhitung 4,19> Qtabel 2,95. 
Jurnal Sporta Saintika

P-ISSN 2502-5651

E-ISSN 2579-5910

- Terdapat perbedaaan keterampilan objek kontrol anak dengan koordinasi tinggi dan rendah, ditemukan bahwa anak kemampuan objek kontrol anak yang memiliki koordinasi tinggi nilai rata-rata yang lebih tinggi jika dibadingkan dengan kemampuan objek kontrol anak yang memiliki koordinasi rendah dengan nilai Qhitung 5,95 > Qtabel 2,95.

- Terdapat interaksi antara feedback dengan koordinasi terhadap penguasaan kemampuan objek control. Berdasarkan tabel output Tests of Between-Subjects Effects di atas didapatkan nilai Sig 0,000 < 0,05. Maka dapat disimpulkan bahwa feedback, koordinasi berpengaruh signifikan terhadap kemampuan gerak dasar anak TK Pembina Padang Panjang.

- Terdapat perbedaan kemampuan objek kontrol anak antara kelompok anak yang meliki koordinasi tinggi diberi feedback langsung dengan anak yang diberi feedback tidak langsung dengan nilai Qhitung 12,03> Qtabel 3,15. Maka hipotesis yang diajukan dapat diterima, bahwa memang terdapat perbedaan kemampuan objek kontrol siswa yang diberikan feedback langsung koordinasi tinggi dan feedback tidak langsung koordinasi tinggi. Idealnya adalah bagi anak yang memiliki koordinasi tinggi lebih efektif menggunakan feedback langsung.

- Terdapat perbedaan kemampuan objek kontrol anak antara kelompok anak yang memiliki koordinasi rendah diberi feedback langsung dengan anak yang diberi feedback tidak langsung dengan nilai Qhitung 4,03> Qtabel 3,15. Maka hipotesis yang diajukan dapat diterima, bahwa memang terdapat perbedaan kemampuan objek kontrol siswa yang diberikan feedback tidak langsung dan feedback langsung dengan koordinasi rendah. Idealnya adalah bagi anak yang memiliki koordinasi rendah lebih efektif menggunakan feedback tidak langsung.

\section{SARAN}

Berdasarkan kesimpulan yang telah dikemukakan diatas, maka disarankan :

1. Perlu diteliti mengenai efek pemberian whey protein terhadap radikal bebas yang merupakan salah satu pemicu kerusakan otot setelah latihan eksentrik

2. Perlu dilakukan penelitian serupa dengan menggunakan beberapa dosis yang berbeda guna mengetahui proses pemulihan secara menyeluruh.

3. Perlu penelitian serupa dengan menggunakan pengukuran secara langsung dengan menggunakan biopsi otot, serta magnetic resonance imaging 
Jurnal Sporta Saintika

P-ISSN 2502-5651

E-ISSN 2579-5910

techniques (MRI), sebagai gambaran yang lebih spesifik mengenai kerusakan otot setelah aktivitas

\section{DAFTAR PUSTAKA}

Kiram, Y. (1994). Kemampuan Koordinasi Gerak dan Klasifikasi Aktifitas. Padang: FPOK IKIP. Padang.

Silverman, S., Tyson, L., \& Krampitz, J. (1992). Teacher feedback and achievement in physical education: Interaction with student practice. Teaching and teacher education, 8(4), 333-344.

Lee , A. M, Keh, A.C, \& Magill, R.A. (1993). Instructional Effects of Teacher Feedback in Physical Eduction. Journal of Teaching in Physical Education, 12 (3) 228-243.

Ulrich, D. A. (2000). Test of gross motor development 2nd edition. Austin, TX: PRO-ED.

Clark, J. E., \& Metcalfe, J. S. (2002). The mountain of motor development: A metaphor. Motor development: Research and reviews, 2(163-190), 183-202.

Malina, R. M., Bouchard, C., \& Bar-Or, O. (2004). Growth, maturation, and physical activity. Human kinetics.

Gallahue DL, Ozmun JC. 2006. Understanding motor development: infants, children, adolescents, adults. 6th ed. Boston (MA): McGraw-Hill.

Nocaise, V;Congerino, G., Boris , J; Amoroso, A.J. (2006). Student Perseption of Teacher Feedback and physical Competence in Physical Education Classes: Gender Effects. Journal of Teaching in Physical Education, 25 (1), 36-57.

Martini. 2007. Prosedur danPrinsip-Prinsip Statistika. Surabaya: Unesa University Press.

Piek, J. P., Dawson, L., Smith, L. M. \& Gasson, N. The role of early fine and gross motor development on later motor and cognitive ability. Human Movement Science, 2008, 27, 668-681.

Stodden, D. F., Goodway, J. D., Langendorfer, S. J., Roberton, M. A., Rudisill, M. E., Garcia, C., \& Garcia, L. E. (2008). A developmental perspective on the role of motor skill competence in physical activity: An emergent relationship. Quest, 60(2), 290-306.

Shenouda, L., Gabel, L., \& Timmons, B. W. (2011). Preschooler focus-physical activity and motor skill development. Child Health \& Exercise Medicine Program, 1, 1-2.

Pope, M. L., Liu, T., \& Getchell, N. (2011). Object-control skills in Hispanic preschool children enrolled in head start. Perceptual and Motor Skills, 112(1), 193-200.

Child Health \& Exercise Medicine Program McMaster University. (2013). Preschooler Physical Activity and Motor Skill 
Jurnal Sporta Saintika

P-ISSN 2502-5651

E-ISSN 2579-5910

Development.https://fhs.mcmaster.ca/chemp/documents/PreschoolerFocuslssue3-

MotorSkills-updatedSECURED.pdf

Bakhtiar, S. (2014). Strategi Pembelajaran, Lokasi Sekolah, Dan Kemampuan Gerak Dasar

Siswa Sekolah Dasar. Jurnal Ilmu Pendidikan Universitas Negeri Malang, 20(2).

Tsapakidou, A., Stefanidou, S., \& Tsompanaki, E. (2014). Locomotor development of children aged 3.5 to 5 years in nursery schools in Greece. Review of European Studies, 6(2), 1.

Gusril. 2015. Perkembangan Motorik pada Masa Anak-Anak. Padang : UNP Press.

Altinkok, Mustafa. (2016). The Effects of Coordination and Movement Education on

PreSchool Children Basic Motor Skills. Improvement Universal Journal of Education Research 4 (5) 1050-1058.

Ružbarská, I. (2016). Physical fitness of primary school children in the reflection of different levels of gross motor coordination. Acta Gymnica, 46(4), 184-192.

Sugiyono. Metode Penelitian Kuantitatif, Kualitatif dan R\&D. Bandung: PT Alfabet. 2016.

Bakhtiar, S., \& Famelia, R. (2017, December). Institute Role of Teachers' Education in Improving the Standard of Development Achievement Rate and Standard of Teacher and Education Personnels of Early Childhood Education. In International Conference of Early Childhood Education (ICECE 2017). Atlantis Press.

Tompsett, C., Sanders, R., Taylor, C., \& Cobley, S. (2017). Pedagogical approaches to and effects of fundamental movement skill interventions on health outcomes: A systematic review. Sports Medicine, 47(9), 1795-1819.

Oktarifaldi, O., Syahputra, R., Putri, L. P., \& Bakhtiar, S. (2019). THE EFFECT OF AGILITY, COORDINATION AND BALANCE ON THE LOCOMOTOR ABILITY OF STUDENTS AGED 7 TO 10 YEARS. Jurnal Menssana, 4(2), 190-200. 